\title{
Pengaruh Informasi Akuntansi Terkait Penerapan IFRS Dalam Menentukan Nilai Pasar Perusahaan Properti Yang Terdaftar Di BEI Tahun 2007-2014
}

\author{
Fabianus Setiawan \\ Program Studi Magister Akuntansi Fakultas Ekonomi \\ Universitas Tarumanagara Jakarta
}

Email: fabianus.setiawan@gmail.com

\begin{abstract}
Abstrak. Penelitian ini bertujuan memperoleh bukti empirik pengaruh book value, net income dan operating cash flow terhadap harga saham perusahaan property periode 2007-2014. Unit penelitian ini adalah laporan keuangan dari 16 perusahaan properti periode 2007-2014. Metode alat analisis menggunakan analisa statistik deskriptif dan regresi robust untuk mengetahui pengaruh secara parsial maupun simultan. Hasil penelitian dengan regresi robust menunjukan hasil: Book value, net income dan operating cash flow secara bersama-sama maupun parsial signifikan mempengaruhi harga saham industri sektor property and buildingconstruction yang telah dan tetap terdaftar di Bursa Efek Indonesia pada periode tahun 2007-2014, baik sebelum maupun sesudahadopsi IFRS. Penerapan konvergensi IFRS juga meningkatkan pengaruhnya informasi akuntansi tersebut terhadap harga saham.
\end{abstract}

Kata kunci:book value, net income, operating cash flow, harga saham, perusahaan property.

\section{PENDAHULUAN}

Standar akuntansi setiap negara berbeda - beda. Perbedaan ini menimbulkan masalah dalam menilai suatu perusahaan. Informasi akuntansi menjadi tidak pasti karena standar yang berbeda. Harta, kewajiban dan modal tidak lagi dapat dinilai dari satu sisi karena setiap negara mempunyai cara sendiri dalam melakukan pencatatan akuntansi.

Liberalisme atau paham kebebasan merupakan paham paling mendasar yang dimiliki manusia. Paham tersebut juga erat penerapannya dalam perkembangan ilmu akuntansi dunia. Liberalisasi menolak batasan terutama terkait dengan perdagangan dan investasi. Paham ini yang mengawali perbedaan standar akuntansi setiap negara.

International Financial Reporting Standards (IFRS) merupakan produk dari International Accounting Standards Board (IASB). Tujuan dari IFRS adalah peningkatan standar kualitas laporan keuangan internasional (Ball, 2006). Penerapan IFRS merupakan salah satu peristiwa penting yang terjadi dalam sejarah akuntansi dunia. IFRS merupakan jawaban dalam upaya untuk menyeragamkan pemahaman informasi akuntansi dalam menilai perusahaan terutama dari sisi pasar modal. Kewajiban untuk mengadopsi IFRS terutama bagi perusahaan yang terdaftar merupakan salah satu peristiwa penting terkait dengan sejarah akuntansi (Daske et al., 2008).

Perdebatan masih terjadi mengenai apakah IFRS dapat meningkatkan kualitas informasi laporan keuangan (Bart et al., 2008; Daske et al., 2008; Karampinis and Hevas, 2011; Alali and Foote, 2012). Informasi akuntansi yang dibuat dengan menggunakan standar IFRS lebih memenuhi kualifikasi ketimbang informasi akuntansi yang disusun menggunakan standar akuntansi lainnya Bartov et al (2005), Liu and Liu (2007), Barth et al., (2008), and Alali and Foote (2012). Van der Meulen (2007); Karampinis and Hevas (2011) menyimpulkan bahwa tidak ada peningkatan signifikan kualitas laporan keuangan setelah adopsi IFRS.

Fakta bahwa informasi keuangan setelah penerapan IFRSsignifikan mempengaruhi secara harga saham di pasar modal. Informasi keuangan yang ditelusuri berasal dari 18 perusahaan properti di Indonesia pada rentang waktu 2007 - 2014. Berdasar rentang waktu tersebut diharapkan terlihat adanya pengaruh penerapan IFRS karena IFRS mulai diimplementasikan tahun 2010.

Selanjutnya dibuktikan dan dikaji teori mengapa IFRS dapat menunjang kualitas informasi akuntansi Book value, net income dan operating cash flow terhadap harga saham.

\section{METODOLOGI PENELITIAN}

Teknik Pengolahan Data dalam penelitian ini menggunakan regresi robust sederhana dan berganda, dengan data panel. Proses analisis data dilakukan dalam penelitian ini menggunakan aplikasi Eviews 9. 
Menggunakan perbandingan nilai adjusted $\mathrm{R}$ square untuk melihat seberapa besar variasi variabel independen mampu menjelaskan variasi variabel dependen data yang digunakan dalam penelitian atas nilai pasar sebelum pengadopsian IFRS periode 2007-2009. Model regresi berganda yang digunakan dalam penelitian ini sebagai berikut:

a. Sebelum pengadopsian IFRS (2007-2009)

$$
\begin{aligned}
& Y_{12}=a+\beta_{1} \cdot X_{1}+e \\
& Y_{12}=a+\beta_{2} \cdot X_{2}+e \\
& Y_{12}=a+\beta 3 \cdot X_{3}+e \\
& Y_{12}=a+\beta_{4} \cdot X_{1}+\beta_{5} \cdot X_{2}+\beta_{6} \cdot X_{3}+e
\end{aligned}
$$

b. Transisi IFRS (2010-2011)

$$
\begin{aligned}
& Y_{12}=\mathrm{a}+\beta_{7} \cdot X_{1}+\mathrm{e} \\
& \mathrm{Y}_{12}=\mathrm{a}+\beta_{8} \cdot X_{2}+\mathrm{e} \\
& \mathrm{Y}_{12}=\mathrm{a}+\beta_{9} \cdot \mathrm{X}_{3}+\mathrm{e} \\
& \mathrm{Y}_{12}=\mathrm{a}+\beta_{10} \cdot \mathrm{X}_{1}+\beta_{11} \mathrm{X}_{2}+\beta_{12} \cdot \mathrm{X}_{3}+\mathrm{e}
\end{aligned}
$$

c. Setelah pengadopsian IFRS (2012-2014)

$$
\begin{aligned}
& Y_{12}=a+\beta_{13} \cdot X_{1}+e \\
& Y_{12}=a+\beta_{14} \cdot X_{2}+e \\
& Y_{12}=a+\beta_{15} \cdot X_{3}+e \\
& Y_{12}=a+\beta_{16} \cdot X_{1}+\beta_{17} \cdot X_{2}+\beta_{18} \cdot X_{3}+e
\end{aligned}
$$

Keterangan notasi:

$\mathrm{Y}_{1}$ : Nilai pasar berdasar harga saham penutupan pada hari pengumuman laporan keuangan

$\mathrm{Y}_{2}$ : Nilai pasar berdasar harga saham penutupan 5 hari setelah pengumuman laporan keuangan

$\mathrm{a}=$ konstanta

$\beta=$ koefisien garis regresi

$\mathrm{X}_{1}$ : Book value

$\mathrm{X}_{2}$ : Net income

$\mathrm{X}_{3}$ : Operating cash flow ((EBIT-Tax)-Depreciation)

$\mathrm{e}=$ standar error

\section{HASIL UJI STATISTIK}

$\mathrm{H}_{01}$ ditolak. Dengan demikian book value, net income dan operating cash flow secara bersama-sama mempengaruhi nilai pasar industri sektor property and buildingconstruction yang telah dan tetap terdaftar di Bursa Efek Indonesia pada periode tahun 2007-2014 secara signifikan.

Tabel 1

Hasil Uji Hipotesis Simultan

\begin{tabular}{|c|c|r|r|c|}
\hline Periode & & Prob (f-Statistik) & $\boldsymbol{\alpha}$ & \multicolumn{1}{c|}{ Kesimpulan } \\
\hline $2007-2009$ & Y1 & 0,000000 & 0,05 & $0,000000<0,05$ Ho1 ditolak \\
\hline $2007-2009$ & Y2 & 0,000000 & 0,05 & $0,000000<0,05$ Ho1 ditolak \\
\hline $2010-2011$ & Y1 & 0,000000 & 0,05 & $0,000000<0,05$ Ho1 ditolak \\
\hline $2010-2011$ & Y2 & 0,000000 & 0,05 & $0,000000<0,05$ Ho1 ditolak \\
\hline $2012-2014$ & Y1 & 0,000000 & 0,05 & $0,000000<0,05$ Ho1 ditolak \\
\hline $2012-2014$ & Y2 & 0,000000 & 0,05 & $0,000000<0,05$ Ho1 ditolak \\
\hline
\end{tabular}

Sumber: data olahan

$\mathrm{H}_{02}, \mathrm{H}_{03}$, danH $\mathrm{H}_{04}$ ditolak, berarti book value,net income,operating cash flowsecara parsial signifikan mempengaruhi nilai pasar industri sektor property and buildingconstruction yang telah dan tetap terdaftar di Bursa Efek Indonesia pada periode tahun 2007-2014 
Tabel 2.

Hasil Uji Hipotesis Parsial

\begin{tabular}{|l|l|l|r|c|c|}
\hline \multicolumn{1}{|c|}{ Periode } & & & Prob (f-Statistik) & $\boldsymbol{\alpha}$ & Kesimpulan \\
\hline $2007-2009$ & Y1 & X1 & 0,000000 & 0,05 & $0,000000<0,05$ Ho2 ditolak \\
\hline $2007-2009$ & & X2 & 0,000668 & 0,05 & $0,000000<0,05$ Ho3 ditolak \\
\hline $2007-2009$ & & X3 & 0,000185 & 0,05 & $0,000000<0,05$ Ho4 ditolak \\
\hline $2007-2009$ & Y2 & X1 & 0,000000 & 0,05 & $0,000000<0,05$ Ho2 ditolak \\
\hline $2007-2009$ & & X2 & 0,000336 & 0,05 & $0,000000<0,05$ Ho3 ditolak \\
\hline $2007-2009$ & & X3 & 0,000163 & 0,05 & $0,000000<0,05$ Ho4 ditolak \\
\hline $2010-2011$ & Y1 & X1 & 0,000000 & 0,05 & $0,000000<0,05$ Ho2 ditolak \\
\hline $2010-2011$ & & X2 & 0,000000 & 0,05 & $0,000000<0,05$ Ho3 ditolak \\
\hline $2010-2011$ & & X3 & 0,000000 & 0,05 & $0,000000<0,05$ Ho4 ditolak \\
\hline $2010-2011$ & Y2 & X1 & 0,000000 & 0,05 & $0,000000<0,05$ Ho2 ditolak \\
\hline $2010-2011$ & & X2 & 0,000000 & 0,05 & $0,000000<0,05$ Ho3 ditolak \\
\hline $2010-2011$ & & X3 & 0,000000 & 0,05 & $0,000000<0,05$ Ho4 ditolak \\
\hline $2012-2014$ & Y1 & X1 & 0,000000 & 0,05 & $0,000000<0,05$ Ho2 ditolak \\
\hline $2012-2014$ & & X2 & 0,000000 & 0,05 & $0,000000<0,05$ Ho3 ditolak \\
\hline $2012-2014$ & & X3 & 0,000000 & 0,05 & $0,000000<0,05$ Ho4 ditolak \\
\hline $2012-2014$ & Y2 & X1 & 0,000000 & 0,05 & $0,000000<0,05$ Ho2 ditolak \\
\hline $2012-2014$ & & X2 & 0,000000 & 0,05 & $0,000000<0,05$ Ho3 ditolak \\
\hline $2012-2014$ & & X3 & 0,000000 & 0,05 & $0,000000<0,05$ Ho4 ditolak \\
\hline
\end{tabular}

Tabel 3.

Nilai R-Squared Regresi Robust Simultan

\begin{tabular}{|c|r|r|l|l|}
\hline Periode & & R-Squared & Penjelasan \\
\hline $2007-2009$ & Y1 & 0,360574 & $\begin{array}{l}36,0574 \% \text { variabel dependen (harga saham industri sektor property and } \\
\text { building construction) dapat dijelaskan oleh variabel independen (book } \\
\text { value, net income dan operating cash flow), dan sisanya sebesar } \\
63,9426 \% \text { dapat dijelaskan oleh variabel lain yang tidak diteliti. }\end{array}$ \\
\hline $2007-2009$ & Y2 & 0,393316 & $\begin{array}{l}39,3316 \% \text { variabel dependen (harga saham industri sektor property and } \\
\text { building construction) dapat dijelaskan oleh variabel independen (book } \\
\text { value, net income dan operating cash flow), dan sisanya sebesar } \\
60,6684 \% \text { dapat dijelaskan oleh variabel lain yang tidak diteliti. }\end{array}$ \\
\hline $2010-2011$ & Y1 & 0,554059 & $\begin{array}{l}\text { 55,4059\% variabel dependen (harga saham industri sektor property and } \\
\text { building construction) dapat dijelaskan oleh variabel independen (book } \\
\text { value, net income dan operating cash flow), dan sisanya sebesar } \\
44,5941 \% \text { dapat dijelaskan oleh variabel lain yang tidak diteliti. }\end{array}$ \\
\hline $2010-2011$ & Y2 & 0,476509 & $\begin{array}{l}47,6509 \% \text { variabel dependen (harga saham industri sektor property and } \\
\text { building construction) dapat dijelaskan oleh variabel independen (book } \\
\text { value, net income dan operating cash flow), dan sisanya sebesar } \\
52,3491 \% \text { dapat dijelaskan oleh variabel lain yang tidak diteliti. }\end{array}$ \\
\hline $2012-2014$ & Y1 & 0,461365 & $\begin{array}{l}46,1365 \% \text { variabel dependen (harga saham industri sektor property and } \\
\text { building construction) dapat dijelaskan oleh variabel independen (book } \\
\text { value, net income dan operating cash flow), dan sisanya sebesar } \\
53,8635 \% \text { dapat dijelaskan oleh variabel lain yang tidak diteliti. }\end{array}$ \\
\hline $2012-2014$ & Y2 & 0,463502 & $\begin{array}{l}46,3502 \% \text { variabel dependen (harga saham industri sektor property and } \\
\text { building construction) dapat dijelaskan oleh variabel independen (book } \\
\text { value, net income dan operating cash flow), dan sisanya sebesar } \\
53,6498 \% \text { dapat dijelaskan oleh variabel lain yang tidak diteliti. }\end{array}$ \\
\hline
\end{tabular}

Nilai R-squared meningkat setelah adopsi IFRS, membuktikan bahwa relevansi nilai informasi akuntansi meningkat setelah adopsi IFRS. 


\section{PEMBAHASAN}

Pengaruh Relevansi Nilai Informasi Laporan Keuangan (Book value, Net Iincome dan Operating Cash Flow) Terhadap Nilai Pasar. Berdasarkan hasil uji Adjusted R Square Total, dapat dikatakan bahwa book value, net income dan operating cash flow memberikan pengaruh yang signifikan terhadap nilai pasar baik periode sebelum pengadopsian IFRS maupun setelah pengadopsian IFRS. Hal ini dikarenakan investor mencari cara penilaian yang tepat bagi manajemen yang menjalankan perusahan. Penilaian investor terhadap relevansi nilai informasi laporan keuangan tidak terlepas dari adanya asimetri informasi antara prinsipal dengan agen. Untuk itu relevansi nilai informasi akuntansi laporan keuangan dinilai oleh investor sebagai kemampuan angka-angka akuntansi untuk merangkum informasi yang mendasari harga saham, sehingga relevansi nilai diindikasikan dengan sebuah hubungan statistikal antara informasi keuangan dan harga atau return saham.

Penjelasan lebih mendalam dapat dilihat dari hasil arah pergerakan Adjusted R Square Total yang menunjukkan periode setelah pengadopsian IFRS meningkat 18,93\% dari periode sebelum pengadopsian IFRS dimana masing-masing nilai Adjusted R Square Total untuk periode setelah pengadopsian IFRS sebesar 50,62\% dan periode sebelum pengadopsian IFRS hanya sebesar 31,69\%. Sedangkan arah pergerakan nilai Adjusted R Square Parsial untuk periode 2007-2008, 2009-2010, dan 2010-2012 juga mengalami kenaikan.

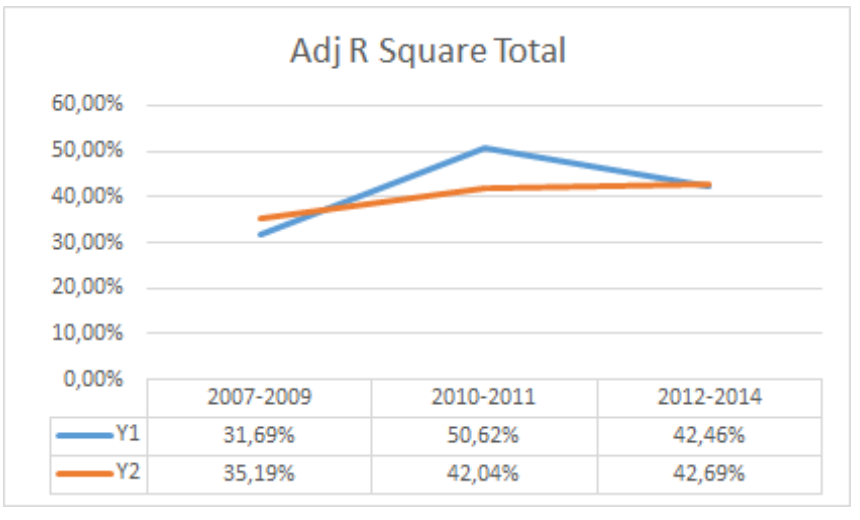

Pengaruh Relevansi Nilai Informasi Laporan Keuangan (Book value) Terhadap Nilai Pasar.

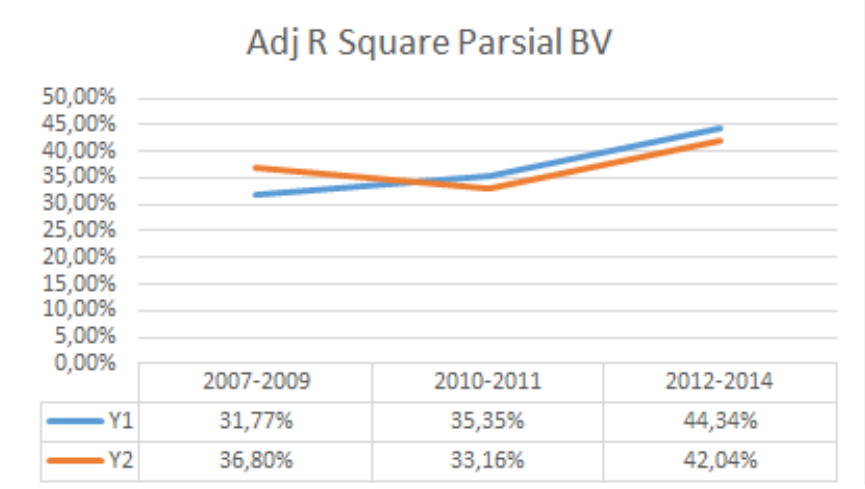

Dari gambar diatas terlihat pada periode pertama (2007-2009) nilai Adjusted R Square All hanya senilai $31,77 \%$ yang kemudian meningkat 3,58\% pada periode kedua (2010-2011) menjadi 35,35\% lalu menjadi 44,34\% pada periode ketiga (2012-2014). Trend tersebut terlihat berbeda 5 hari setelah laporan keuangan diterbitkan dimana terjadi penurnan 3,64\% dari periode pertama (2007-2009) dari 36,80\% menjadi 33,16\% pada periode kedua (2010-2011).

Berdasarkan hasil di atas dapat disimpulkan bahwa investor menggunakan nilai book value perusahaan untuk menilai harga saham perusahaan. Book value menjadi fokus penilaian perusahaan dari investor karena 
adopsi standar pelaporan yang baru yaitu IFRS yang lebih menekankan pelaporan nilai wajar sehingga terjadi peningkatan relevansi nilai informasi book value.

Pengaruh Relevansi Nilai Informasi Laporan Keuangan (Net income) Terhadap Nilai Pasar. Net income memberikan pengaruh terhadap nilai pasar periode setelah pengadopsian IFRS. Dari gambar dibawah terlihat terjadi peningkatan signifikan nilai Adjusted R Square Parsial NI sebesar 40,67\% pada periode pertama (2007-2009) yang hanya senilai 4,72\% menjadi 45,39\% pada periode kedua (2010-2011) lalu menurun menjadi 43,17\% pada periode ketiga (2012-2014). Trend yang sama terlihat 5 hari setelah laporan keuangan diterbitkan dimana terjadi peningkatan 43,62\% dari periode pertama (2007-2009) dari 4,59\% menjadi 48,21\% pada periode kedua (2010-2011).

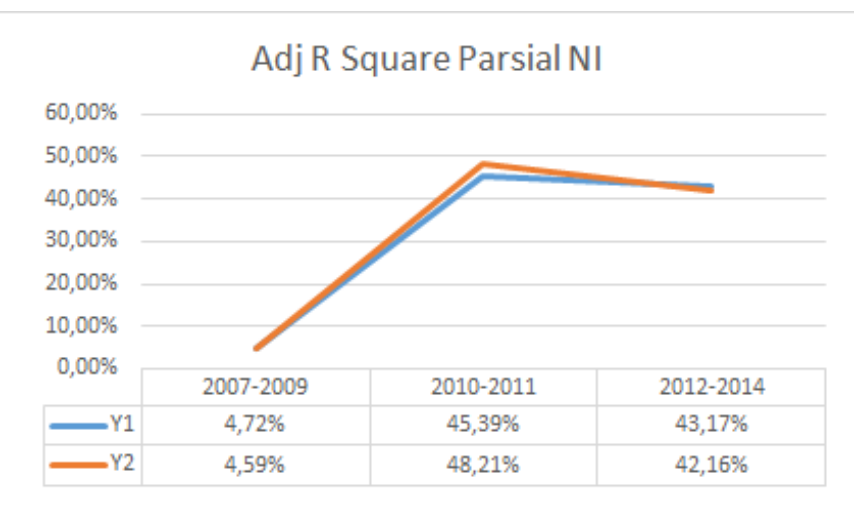

Pengaruh Relevansi Nilai Informasi Laporan Keuangan (Operating cash flow) Terhadap Nilai Pasar. Operating cash flow memberikan pengaruh terhadap nilai pasar periode setelah pengadopsian IFRS. Dari gambar terlihat terjadi peningkatan signifikan nilai Adjusted R Square NI sebesar 38,92\% pada periode pertama (2007-2009) yang hanya senilai 7,42\% menjadi 46,34\% pada periode kedua (2010-2011) lalu menurun menjadi 41,78\% pada periode ketiga (2012-2014). Trend yang sama terlihat 5 hari setelah laporan keuangan diterbitkan dimana terjadi peningkatan 43,98\% dari periode pertama (2007-2009) dari 7,60\% menjadi 51,58\% pada periode kedua (2010-2011).

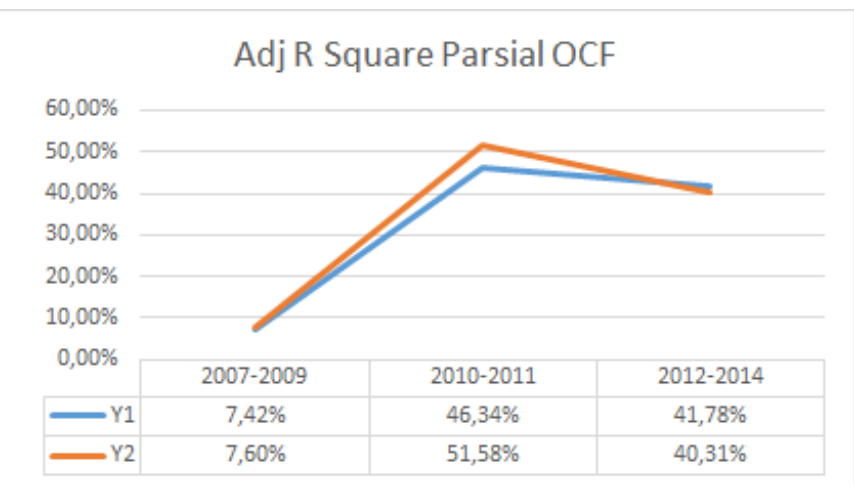

\section{PENUTUP}

Relevansi nilai informasi laporan keuangan khususnya book value, net income dan operating cash flow sebelum dan setelah pengadopsian IFRS secara bersama-sama signifikan mempengaruhi nilai pasar industri sektor property and buildingconstruction yang telah dan tetap terdaftar di Bursa Efek Indonesia pada periode tahun 2007-2014..

Relevansi nilai informasi laporan keuangan khususnya book value sebelum dan setelah pengadopsian IFRS secara parsial signifikan mempengaruhi nilai pasar industri sektor property and buildingconstruction yang telah dan tetap terdaftar di Bursa Efek Indonesia pada periode tahun 2007-2014 . 
Relevansi nilai informasi laporan keuangan khususnya net income sebelum dan setelah pengadopsian IFRS secara parsial signifikan mempengaruhi nilai pasar industri sektor property and buildingconstruction yang telah dan tetap terdaftar di Bursa Efek Indonesia pada periode tahun 2007-2014 .

Relevansi nilai informasi laporan keuangan khususnya operating cash flow sebelum dan setelah pengadopsian IFRS secara parsial mempengaruhi nilai pasar industri sektor property and buildingconstruction yang telah dan tetap terdaftar di Bursa Efek Indonesia pada periode tahun 2007-2014.

Bagi penelitian selanjutnya dapat mempertimbangkan dan menambah faktor-faktor lain diluar penelitian ini yang diduga juga memiliki pengaruh terhadap nilai pasar untuk diteliti lebih lanjut. Mengembangkan industri yang dikaji dengan mengaitkan hubungan industry property dengan industry perbankan dan industry retail.Bagi perusahaan property and buildingconstruction, sebaiknya lebih memperhatikan faktor-faktor penentu harga saham yang mempengaruhi nilai pasar perusahaan.

\section{DAFTAR PUSTAKA}

Alali, F.A., and Foote, P.S. 2012. The Value Relevance Of International Financial Reporting Standards: Empirical Evidence in an Emerging Market. The International Journal of Accounting.

Aussenegg, W., Petra Inwinkl, and Georg Schneider. 2009. Earnings Management and Accounting Standards in Europe. Proceedings of the 2009 MFA Annual Meeting.

Badshaw and Miller. 2007. Have Financial Statements Lost Their Relevance?. Journal Accounting Research.

Ball, R. 2006. Internasional Financial Reporting Standards (IFRS): Pros and cons forinvestors. Accounting $\&$ Business Research, International Accounting Policy Forum.

Ball, Ray, and Philip Brown. "An empirical evaluation of accounting income numbers." Journal of accounting research (1968): 159-178.

Ball, R., A. Robin, and J.S Wu, 2003. Incentives versus Standards: Properties of Accounting in Four East Asian Countries. Journal of Accounting and Economics.

Barth, M.E., W.R. Landsman, and M.H. Lang. 2008. International Accounting Standards and Accounting Quality. Journal of Accounting Research.

Bartov, E., Goldberg, S. and Kim, M. 2005. Comparative Value Relevance Among German, U.S. and International Accounting Standards: A German Stock Market Perspective. Journal of Accounting.

Capkun, V., Daniel W. Collins and Thomas Jeanjean. 2011. Does Adoption of IAS/IFRS Deter Earnings Management. Finance Working Paper.

Carlo, S., dan Jarne, J. 2010. Have IFRS Affected Earnings Management in The European Union?. Journal of Accounting in Europe Vol. 7.

Choi and Meek. 2005. International Accounting, Edisi 5. Journal of Accounting.

Choi, F., D.S.Frost, Carol A. and Meek, Gary K. 1999. International Accounting. Prentice Hall, Upper Saddle River, NY.

Christensen, H.B., M. Walker, and E. Lee. 2008. Incentives or Standards: What Determines Accounting Quality Changes Around IFRS Adoption?. Working Paper.

Darmawan, Sintje. 2011. "Pengaruh Harga Saham, Dividen, Risiko Pasar dan Risiko Perusahaan Terhadap Return Yang Diharapkan Investor Pada Perusahaan Yang Ada Di LQ 45 Periode Tahun 20072009".Jakarta: Universitas Tarumanagara.

Daske, H., L. Hail, C. Leuz, and R. Verdi. 2008. Mandatory IFRS Reporting around the World: Early Evidence on the Economic Consequences. Journal of Accounting Research.

Djankov. 2008. Pengaruh Konservatisme Laporan Keuangan Terhadap Earnings Response Coefficient. Jurnal Riset Akuntansi Indonesia.

Francis, J. and Schipper, K. 1999. Have Financial Statements Lost Their Relevance. Journal of Accounting Research.

Gebhardt, and Farkas. 2011. Macroeconomic Influences On The Stock Market. Journal of Economics and Finance. 
Hung, M., and K. Subramanyam. 2007. Financial Statement Effects of Adopting International Accounting Standards: the case of Germany. Review of Accounting Studies.

Hutagaol, A. 2010. Hubungan Pengadopsian IFRS dengan Kualitas Laba Akuntansi. Universitas Gadjah Mada.

Indra, and Fazli, 2004. Hubungan Laba Akuntansi, Nilai Buku, Dan Total Arus Kas Dengan Market Value : Studi Akuntansi Relevansi Nilai, Simposium Nasional Akuntansi VII, 2-3 Desember 2004.

Karamanou. I, and Nishiotis. G.P. 2009. Disclosure and the Cost of Capital: Evidence from the Market's Reaction to Firm Voluntary Adoption of IAS. Jurnal of Business Finance \& Accounting.

Karampinis, N., and Hevas, D. 2011. Mandating IFRS in an Unfavorable Environment: The Greek Experience. The International Journal of Accounting.

Kusuma, I.W. 2007. Pengadopsian International Financial Reporting Standards: Implikasi untuk Indonesia. Universitas Gadjah Mada.

Liu, J., \& Liu, C. 2007. Value Relevance Of Accounting Information In Different Stock Market Segments: The Case of Chinese A-,B- and H-shares. Journal of International Accounting Research.

Maruli. 2010. Problematika Konvergensi Standar Akuntansi. Media Akuntansi, Jakarta

Pacter, P. 2005. What exactly is convergence?. International Journal Accounting, Auditing and Performance Evaluation.

Pinasti, M., 2004. Faktor - Faktor Yang Menjelaskan Variasi Relevansi - Nilai Informasi Akuntansi : Pengujian Hipotesis Informasi Alternatif. Simposium Nasional Akuntansi VII, 2-3 Desember 2004.

Rahmellia, A.S. 2009. Earnings Management dan Nilai Relevansi Laba sebelum dan setelah Pengadopsian IFRS. Universitas Gadjah Mada.

Roberts, D.A., A. Dey, and T.Z. Lys. 2005. Incentives or Standards: What Determines Accounting Quality Changes Around IFRS Adoption?. Financial Accounting and Reporting Section (FARS) Paper.

Sarwono, J. (2016). Prosedur-Prosedur Analisis Populer Aplikasi Riset Skripsi dan Tesis dengan Eviews. Jakarta: Penerbit Gaya Media.

Siregar, and Utama. 2008. The Impact of Mandatory IFRS Adoption on Foreign Mutual Fund Ownership: The Role of Comparability. Jurnal of Accounting and Economics.

Skousen, K.F., Stice, Earl K., and Stice, James D.2000.Intermediate Accounting $14^{\text {th }}$ ed. South Western Thomson Learning Inc.

Suharli, and Rachpriliani. 2006. Studi Empiris Faktor yang Berpengaruh Terhadap Ketepatan Waktu Pelaporan Keuangan. Jurnal Bisnis dan Akuntansi.

Susanto, Edi. 2009. "Pengaruh Return on Asset (ROA), Return on Equity (ROE), Earning Per Share (EPS) dan Profit Margin Ratio (PMR) Terhadap Harga Saham".Jakarta: Universitas Tarumanagara.

Tanudiredja, Mario. 2011. "Pengaruh Earning Power Ratio (EPR), Earning Per Share (EPS), Return on Sales (ROS) Terhadap Harga Saham Perusahaan di Sektor Industri Manufaktur Yang Terdaftar di Bursa Efek Indonesia Selama Periode Tahun 2006-2009". Jakarta: Universitas Tarumanagara.

Triyono, and Jogiyanto. 2008. Akuntansi Perbankan Transaksi dalam Valuta Rupiah edisi ketiga.Yogyakarta.

Van der Meulen, S., Gaeremynck, A., and Willekens, M. 2007. Attribute Difference Between US GAAP and IFRS Earnings: An exploratory studdy. The International Journal of Accounting.

Vroom, Victor. "Expectancy theory." Work and motivation (1964).

Widianty, Djap. 2009. "Pengaruh Audit Opinion, Laba (Rugi) Perusahaan, Rasio Profitabilitas, Rasio Solvabilitas, dan Ukuran KAP Terhadap Audit Delay Pada Perusahaan-Perusahaan Manufaktur Yang Terdaftar di Bursa Efek Jakarta Periode 2005-2007 ".Jakarta: Universitas Tarumanagara. 